\title{
Distribution and status of the Apennine hare Lepus corsicanus in continental Italy and Sicily
}

\author{
Francesco M. Angelici and Luca Luiselli
}

\begin{abstract}
The current distribution of Lepus corsicanus (recently considered to be a distinct species from L. europaeus) in peninsular Italy and Sicily is presented in this paper. Our data suggest that $L$. corsicanus is declining markedly in mainland Italy, and perhaps also in Sicily, and that it should be categorised as Endan-
\end{abstract}

gered on the IUCN Red List. Conservation recommendations for this species are presented.

Keywords conservation, distribution, Italy, Lepus corsicanus, status.

\section{Introduction and historical background}

In 1898 a new hare Lepus corsicanus native to Corsica was described (De Winton, 1898). Descriptions of its morphometric and morphological characteristics can be found in Palacios et al. (1989), Palacios (1996) and Angelici \& Luiselli (2000). De Winton suggested that this hare was also found in central and southern Italy, Sicily and Elba. Of the 'historical' specimens in various collections, the northernmost came from Elba, whereas the northernmost in mainland Italy came from the province of Sienna (Fig. 1). However, these sites, derived from random captures, do not reliably describe the species' distribution. L. corsicanus was later considered to be a subspecies of the European hare $L$. europaeus (Miller, 1912; Ellerman \& Morrison-Scott, 1951; Toschi, 1965), but the morphometric data of Palacios (1996) and recent mithocondrial DNA data confirmed the specific status of L. corsicanus (Pierpaoli et al., 1999). With regard to Corsica, the species was likely to have been imported from mainland Italy by Pisans in the XVIth century, when they dominated the Island, or perhaps even earlier (Vigne, 1992). In any case, it seems that the species is now practically extinct from the whole of Corsica (Dubray, 1984; R. Péroux, in litt.).

Following extensive restocking with European hares imported from northern and eastern Europe by hunters (Angelici, 1995; Angelici et al., 2000), it was suggested that Italian $L$. corsicanus could no longer be recognized due to hybridization, although to date there have been no hybrids captured. Angelici (1989)

F. M. Angelici (corresponding author) Italian Foundation of Vertebrate Zoology (FIZV) - Mammal Section, Via Cleonia 30, I-00152 Roma, Italy. E-mail: frangema@tiscalinet it

L. Luiselli Italian Foundation of Vertebrate Zoology (F.I.Z.V.) - Herpetological Section, Via dei Cochi 48/B, I-00133 Roma, Italy. E-mail: lucamlu@tin.it

Revised manuscript accepted for publication 16 January 2001 collected hares during the 1980s and identified an additional characteristic of $L$. corsicanus from northern Latium (central Italy); this was an anthracite-grey colouration of the nape of the neck. Angelici \& Luiselli (2000) analysed a sample of freshly killed hares ( $n=42$ ) and showed that L. europaeus and L. corsicanus are clearly different in terms of six biometric characteristics. These results seem to confirm Palacios's (1996) opinion on the specific status of $L$. corsicanus. Amori et al. (1996) proposed the common name of Apennine hare for L. corsicanus, with emphasis on its biogeographic, and not ecological, characteristics. The same common name was later used by Lo Valvo et al. (1997) and Amori et al. (1999).

In this paper, we present an up-to-date examination of the distribution of the Apennine hare in peninsular Italy and Sicily, based on new field data. In particular, we highlight the extreme rarity of this 'cryptic species', suggest a Red List categorisation, and make recommendations to preserve remaining wild populations.

\section{Methods}

All data used here were collected over 1981-1998 in 40 localities of peninsular Italy and Sicily (Fig. 1) within the previously known range (Toschi, 1965) of this 'race'. The localities were not a priori selected, but depended on the availability of shot specimens. Only adults (sensu Broekhuizen \& Maaskamp, 1979) were considered for the present study.

To investigate the capture of Apennine hares over time, we divided the total number (L. europaeus and L. corsicanus) shot by hunters into two time periods (1981-90 and 1991-98). For both of these periods we surveyed the same localities in peninsular Italy. For Sicily, data were only available for 1991-98. To compare different geographical areas, we divided the data into three regional groups: Central Italy (Latium and 
Abruzzo), Southern Italy (Campania, Molise, Lucania, Apulia and Calabria), and Sicily (Table 1, Fig. 2).

\section{Results and discussion}

\section{Distribution and status}

The presence of the Apennine hare was ascertained at 35 localities during 1981-90, and at 28 localities during 1991-98. The northernmost and southernmost localities where the Apennine hare was shot in continental Italy were, respectively, Farnese (Latium), and Delianuova (Calabria). In Sicily the species is widespread (Lo Valvo et al., 1997), and the southernmost place of capture was Riesi. On mainland Italy, the Apennine hare is found in Latium along the Tyrrhenian slope, and in the Apennines the northernmost population is found in the Central Apennine (Latium and Abruzzo regions). Along the Adriatic slope we are aware of just two records, from Molise and Apulia. Along the slope facing the Ionian Sea, the Apennine hare is still present.
With regard to population abundance and distribution changes, note that most of the records for the Apennine of Latium-Abruzzo are in the 1980s. The species was shot in more recent years, but with few specimens in each of the three groups of localities (just 8-26 per cent of the total Lepus sample examined, Table 1). The frequency of occurrence of the Apennine hare decreased significantly in central Italy from 19.7 per cent (1981-90) to 8.2 per cent (1991-98) (Yate's corrected $\chi^{2}$ test $=2.078$, d.f. $=1$, $P<0.75)$ and in southern Italy from 26.1 per cent (1981-90) to 16.7 per cent (1991-98) (difference not significant, Yate's corrected $\chi^{2}$ test $=0.451$, d.f. $=1$, $P>0.5$ ). These decreases may suggest that Apennine hares are experiencing a general decline in the whole of mainland Italy, although more detailed information is necessary to draw any firm conclusions.

With regard to Sicily, there was only a single capture of the European hare in the early 1990s (Table 1). At present the European hare seems to be completely absent from Sicily due to its inability to establish stable populations in the wild (Lo Valvo et al., 1997), and the Apennine hare seems to be the only species present.

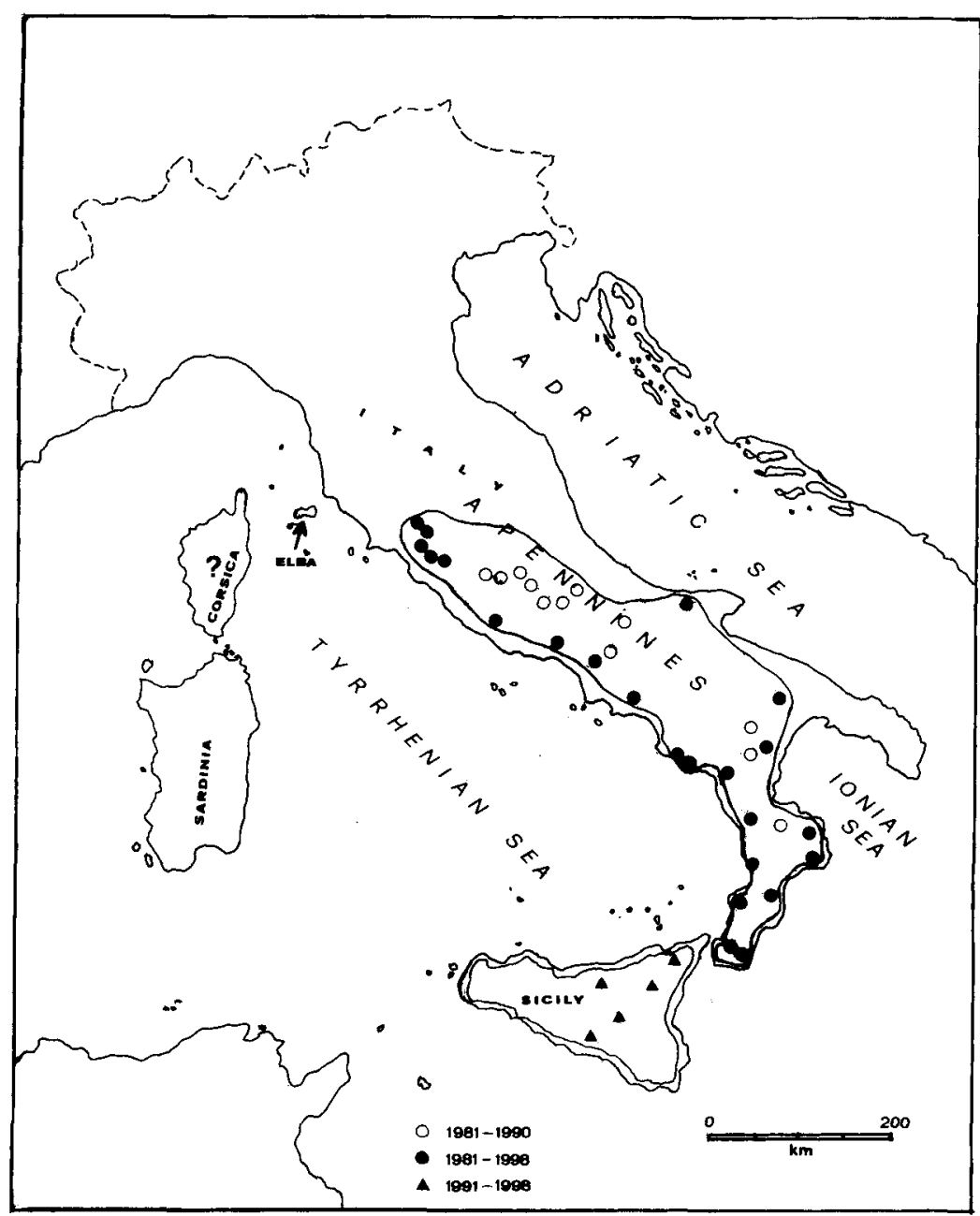

Fig. 1 Possible reconstruction of the original range of Lepus corsicanus. In mainland Italy white dots indicate the localities where the presence of $L$. corsicanus was confirmed during 1981-90 but not 19911998, and black dots during both 1981-90, and 1991-98. In Sicily black triangles indicate the localities where the presence of $L$. corsicanus was confirmed during 1991-98. 
Table 1 Summary of the data on the numbers of hunted Lepus specimens in two time intervals. Every group consisted of all the specimens examined from various localities within the main geographical region indicated in the table.

\begin{tabular}{|c|c|c|c|c|}
\hline & \multicolumn{2}{|c|}{$\begin{array}{l}\text { Total hares } \\
\text { (L. europaeus + } \\
\text { L. corsicanus) }\end{array}$} & \multicolumn{2}{|c|}{ L. corsicanus } \\
\hline & $1981-90$ & $1991-98$ & $1981-90$ & 1991-98 \\
\hline $\begin{array}{l}\text { Central Italy (Latium, } \\
\text { Abruzzo) }\end{array}$ & 61 & 73 & 12 & 6 \\
\hline $\begin{array}{l}\text { Southern Italy (Campania, } \\
\text { Molise, Lucania, } \\
\text { Apulia, Calabria) }\end{array}$ & 46 & 54 & 12 & 9 \\
\hline Sicily & * & 8 & * & 7 \\
\hline
\end{tabular}

*data not available.

The Apennine hare appears to be very well adapted to life in evergreen Mediterranean maquis habitats and in open grasslands with bushy pastures
(Angelici \& Luiselli, 2000). Its occurrence in the latter habitat is not surprising as nearly all species of the genus Lepus are typically inhabitants of grassy and bushy pastures. The fact that the presence of evergreen maquis strongly influences the presence of the Apennine hare is more interesting, and may have important consequences for the conservation of this species.

\section{Conservation and management priorities}

It is difficult to establish an effective strategy for the conservation of the remnant populations of the Apennine hare. The Apennine species is not listed under Italian law among those used for hunting, so it will be necessary to inform hunters about the morphological differences between the European and Apennine hares. The Apennine hare is also omitted from the 2000 IUCN Red List (Hilton-Taylor, 2000).
Fig. 2 Map of the regions of Italy. $\mathrm{AV}=$ Aosta Valley; PM = Piedmont; $\mathbf{L I}=$ Liguria; $\mathrm{LO}=$ Lombardy; $\mathrm{TR}=$ Trentino-Alto Adige; $\mathrm{VE}=$ Venetia; FR = Friuli-Venetia Julia; ER = EmiliaRomagna; $\mathrm{TU}=$ Tuscany; $\mathrm{MA}=$ Marches; $\mathrm{UM}=$ Umbria; $\mathrm{LA}=$ Latium; $\mathrm{AB}=$ Abruzzo; $\mathrm{MO}=$ Molize; $\mathrm{CA}=$ Campania; $\mathrm{AP}=$ Apulia; $\mathrm{LU}=$ Lucania; $\mathrm{CL}=$ Calabria; SI = Sicily; $\mathrm{SA}=$ Sardinia.

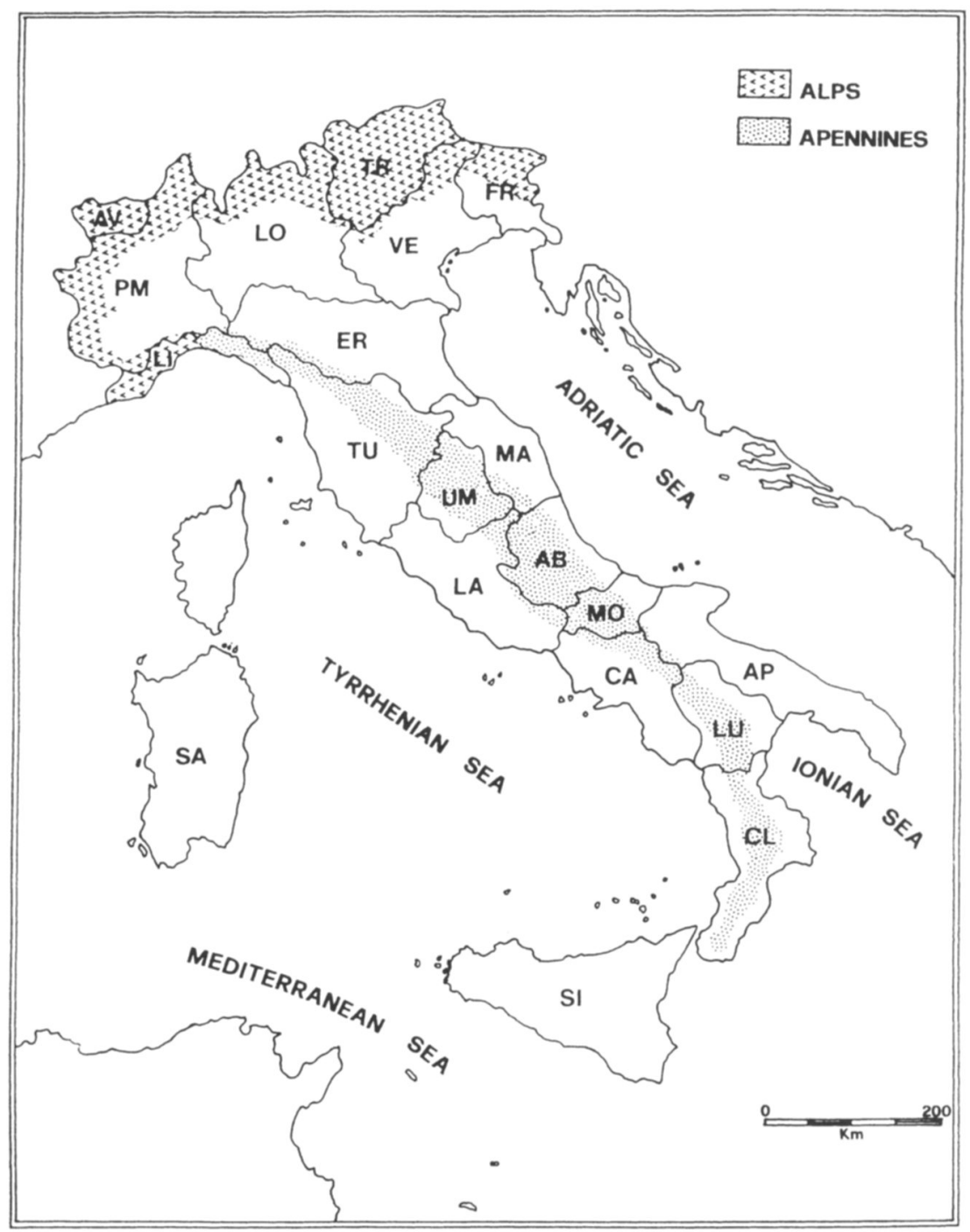


Another problem is interspecific competition between the two hare species (Angelici \& Luiselli, 2000), which should be minimised, or at least limited, by impeding coexistence of the two species. This aim would be achieved by prohibiting the restocking with the European hare in those areas potentially inhabited by the Apennine hare. The introduction of such a strategy would also preserve the remnant autochtonous populations of the European hare by preventing any potential for hybridization with restocked European hares. In practice, we suggest forbidding restocking from LatiumAbruzzo to the south, and in Sicily. Despite the enormous number of restocked hares (at least 10,000 up to 1995; Lo Valvo et al., 1997), the European hare seems not to have established in Sicily.

Another urgent conservation priority should be to carefully census the numbers of Apennine hares. Based on indirect evidence (few records in recent years, interviews with hunters and people working in wildlife parks and protected areas) we are led to believe that the species is rare in mainland Italy, whereas in Sicily it seems relatively more abundant, but possibly in decline (Lo Valvo et al., 1997).

Although some natural habitats of the Apennine hare fall within protected areas, these areas need to be organized into a system of faunal corridors. This might permit the Apennine hare to survive, and possibly to expand its range (Gilpin \& Soulé, 1986; Gilpin, 1987). The actual range of the Apennine hare is likely to be a remnant distribution of a previously widespread Mediterranean species that has been drastically reduced by the invasion of Euro-Asiatic L. europaeus. Careful monitoring of European hare introductions is necessary to protect the few remnant populations of the Apennine hare, which is now considered a threatened species in its whole distribution range (Angelici, 1998, 1999).

In conclusion, the Apennine hare should be categorized as Endangered on the IUCN Red List (HiltonTaylor, 2000) based on criteria A1a; i.e. a population reduction (A) in the form of an observed reduction of at least $50 \%$ over the last 10 years (1), based on direct observation (a). In the near future it may become necessary to maintain captive bred populations of Apennine hares for future re-establishment of freeranging groups in the areas where it has disappeared.

\section{Acknowledgements}

We are greatly indebted to the many hunters who permitted us to examine and record measurements from their hares. C. Anibaldi, A. Coletti, G. Paoloni, G. Nascetti, G. Aloise, P. Andreani, U. De Giacomo, S. Fracasso, E. Filippi, A. Pazienti, D. Persichetti,
E. Politano, R. Luiselli, F. Balmas, A. Barera, S. Seminara and M. Lo Valvo provided us with valuable information. B. D. Rossetti improved our English style. J.G.C. Flux, C. Erskine and two anonymous referees critically commented upon a draft version of this paper.

\section{References}

Amori, G., Angelici, F.M. \& Boitani, L. (1999) Mammals of Italy: a revised list of species and subspecies. Senckenbergiana Biologica, 79, 271-286.

Amori, G., Angelici, F.M., Prigioni, C. \& Vigna Taglianti, A. (1996) The Mammal fauna of Italy: A review. Hystrix, 8, 3-7. Angelici, F.M. (1989) I mammiferi dei Monti Cimini e Vicani: popolamento faunistico, confronto con altre aree del Lazio, e considerazioni zoogeografiche. MSc Thesis. 'La Sapienza' University of Rome, Rome.

Angelici, F.M. (1995) Ecologia della lepre europea Lepus europaeus Pallas 1778 nel Pre-Appennino laziale. Analisi di individui immessi per il ripopolamento venatorio. PhD Thesis. 'La Sapienza' University of Rome, Rome.

Angelici, F.M. (1998) Lepre europea (autoctona) Lepus europaeus meridiei, Lepre appenninica Lepus corsicanus, Lepre sarda Lepus capensis mediterraneus. In Libro Rosso Degli Animali d'Italia. Vertebrati (eds F. Bulgarini, E. Calvario, F. Fraticelli, F. Petretti \& S. Sarrocco), pp. 116-117. WWF Italia, Roma.

Angelici, F.M. (1999) Lepus corsicanus de Winton, 1898. In The Atlas of European Mammals (eds A. Mitchell-Jones, G. Amori, W. Bogdanowicz, et al.), pp. 64-165. Academic Press, London.

Angelici, F.M. \& Luiselli, L. (2000) Body size, range, and ecological coexistence of two hare species (Lepus europaeus and Lepus corsicanus) in Italy, with biogeography and conservation implications. Ecologie, 33, in press.

Angelici, F.M., Riga, F., Boitani, L. \& Luiselli, L. (2000) Fate of captive-reared brown hares Lepus europaeus released at a mountain site in central Italy. Wildife Biology, 6, 173-178.

Broekhuizen, S. \& Maaskamp, F. (1979) Age determination in the European hare (Lepus europaeus Pallas) in the Netherlands. Zeitschrift für Sugetierkunde, 44, 162-175.

De Winton, W.E. (1898) On the hares of Western Europe and North Africa. Annual Magazine of Natural History London, 1, 149-158.

Dubray, D. (1984) Rèpartition des Lagomorphes (Lièvre commun et Lapin de garenne) en Corse. Bulletin Mensuel de l'Office National de la Chasse, 85, 36-38.

Ellerman, J.R. \& Morrison-Scott, T.C.S. (1951). Checklist of Palaearctic and Indian Mammals 1758-1946. Trustees of the British Museum (Natural History), London.

Gilpin, E. (1987) Spatial structure and population vulnerability. In Viable Populations for Conservation (ed. M. E. Soulé), pp. 125-140. Cambridge University Press, Cambridge.

Gilpin, E. \& Soulé, M.E. (1986) Minimum viable populations: processes of species extinction. In Conservation Biology. The Science of Scarcity and Diversity (ed. M. E. Soulé), pp. 19-34. Sinauer Associates, Sunderland.

Hilton-Taylor, C. (Compiler) (2000). IUCN Red List of Threatened Species. IUCN Species Survival Commission, IUCN, Gland.

Lo Valvo, M., Barera, A. \& Seminara, S. (1997) Biometria e status della Lepre appenninica (Lepus corsicanus de Winton 1898) in Sicilia. Il Naturalista Siciliano, 21, 67-74. 
Miller, G.S. (1912) Catalogue of the Mammals of Western Europe (Europe exclusive of Russia) in the Collection of the British Museum. British Museum (Natural History), London.

Palacios, F. (1996) Systematics of the indigenous hares of Italy traditionally identified as Lepus europaeus Pallas, 1778 (Mammalia: Leporidae). Bonner Zoologische Beitrage, 46, 59-91.

Palacios, F., Orueta, J.F. \& Tapia, G.G. (1989) Taxonomic review of the Lepus europaeus group in Italy and Corsica. In Fifth International Theriological Congress (Rome, 1989). Abstract of papers and posters, I, 189-190. Rome.

Pierpaoli, M., Riga, F., Trocchi, V. \& Randi, E. (1999) Species distinction and evolutionary relationships of the Italian hare (Lepus corsicanus) as described by mitochondrial DNA sequencing. Molecular Ecology, 8, 1805-1817.

Toschi, A. (1965) Fauna D'italia. Mammalia. Lagomorpha -Rodentia - Carnivora - Artiodactyla - Cetacea. Calderini, Bologna.

Vigne, J.-D. (1992) Zooarchaeology and the biogeographical history of the mammals of Corsica and Sardinia since the last ice age. Mammal Review, 22, 87-96.

\section{Biographical sketches}

Francesco M. Angelici, PhD in Evolutionary Biology, is a mammalogist based at the Italian Foundation of Vertebrate Zoology and at the Institute Demetra, where he supervises projects concerning the ecology and management of lagomorphs, carnivores, ungulates and rodents, in both Italy and Africa. He has published many papers on mammals, birds and reptiles, is a member of various IUCN/SSC groups, and is coauthor of the Action Plan of Lepus corsicanus, published by the Italian Ministry of Environment. $\mathrm{He}$ is working currently on several conservation projects on threatened mammal species sponsored by National Parks and Reserves.

Luca Luiselli is a herpetologist based at the Italian Foundation of Vertebrate Zoology and at the Institute Demetra, where he supervises projects concerning the ecology and ethology of snakes, chelonians, crocodiles and amphibians in both Italy and Africa. He has published many papers on reptiles, amphibians and mammals, is a member of the International Editorial Board of the journals AmphibiaReptilia and Herpetozoa, is the chairman of IUCN/SSC DAPTF for Nigeria, and is currently working on conservation programmes for threatened Italian snakes on behalf of the Italian Ministry of Environment and National Parks and Reserves. 